\title{
The Relationship between Management Information Systems and Total Quality Management: A Survey Study at Missan Oil Company in Iraq
}

\author{
Reyath Thea Azeez \\ Department of Business Administration \\ Collage of Business and Economic \\ Missan University, Missan, Iraq. \\ Kamarul Bahari Yaakub \\ Department of Business and Entrepreneurship \\ Faculty of Management and Economics \\ Universiti Pendidikan Sultan Idris, Tg Malim, Malaysia.
}

\begin{abstract}
Problem statement: The aim of this research is an endeavor to examine the relationship between Management Information System (MIS) and Total Quality Management (TQM) at Missan Oil Company in Iraq. Approach: The quantitative method used the questionnaire-survey and structural equation modeling (SEM).A total of 250 questionnaires was distributed and a high rate of return (87.6\%) has been achieved. After initial data screening, 201 responses were utilised to analysis the final data. Results: MIS indicators, namely system quality, information quality, use MIS, user satisfaction and net benefits are directly linked with the TQM. Conclusion/Recommendations: Findings of this study are useful for the Iraqi oil sector to enhance the application of TQM through the use of appropriate MIS indicators.
\end{abstract}

Keywords: Management Information System; MIS; Total Quality Management; TQM; Missan Oil Company; SEM; Iraq.

\section{Introduction}

Today, we are living in an era of acceleration of technological inventions in all areas of life. Among these inventions, there is a major development in information technology (IT). The more the development manage of business firms deal with such innovations, the more it is utilised to achieve the goals of their companies, and to maintain a suitable place among private firms to work in the same industry or service. One of the modern management tools used by global companies is TQM which has functioned to change the balance and prejudices of industries and services which has attributed to an advanced country, specially developed countries, where it first started. TQM was first introduced in Japan and has been an applied by organisations to invade western societies through excellence and superiority in most performance aspects, reliability and efficiency, competitive price and all through the implementation of the standards called TQM (Almashaqba, 2013).

In order to ensure its viability and growth, the organisation's fundamental objective is to support the MIS as it aims to produce information that guides management to meet these challenges. The most important of these challenges is the need for the organisations to implement the TQM system with all its requirements and stages. This system has the advantage of ensuring the survival of organisations in a highly competitive business world (Zbar, 2009). Though the researcher's realization that some of the literature is related to MIS and TQM, nevertheless the prosperity of the company depends on its capability to improve decisions by improving the quality of information processing in MIS by adopting TQM and thus improving organizational performance. Therefore, this study aims at clarifying the relationship between MIS and TQM at Missan Oil Company in Iraq.

\section{Literature Review}

The philosophy of TQM principle is that continuous improvement leads to a continuous flow of change requesting for information systems (Spencer \& Duclos, 1998). The factors working on the success of the TQM application involve an ability to manage quality information, automation, and rationalisation of production. Therefore, increasingly organisations found that IT and information systems are the main TQM's success factors. Thus, through the application of MIS, organisations should be able to implement TQM better (Lin, et al, 2012). 
Actually, TQM and information systems have mutual goals. In most companies, some of the basic aims TQM are increasing competitiveness and effectiveness by improving product quality and processing to fulfill both the needs of the consumer and the firm. While the goals of information systems are quality development, improved services, increase production, reduce costs, and increasing the competitiveness of a firm (Fok, et al, 2001). Many researchers have addressed the relationship between MIS and TQM, where the study of Fok et al., (2001)investigated the relationships between TQM and improving information systems. Precisely, they looked at whether companies that had fully adopted TQM would be different in their methods of improving information systems. The results indicated that if TQM is fully adopted, there will be an important effect on four areas for improving information systems. These are system objectives; philosophy /system design; the assumptions made by information systems specialists about the users of the system and user participation in the system development. Also, the study report shows evidence that both TQM and IT may entail analogous organisation cultures. The study by Dewhurst, et al, (2003) investigated the relationship between IT and TQM through an interview survey of 14 organisations based in Spain. In this study, nine dimensions of TQM are used to support top management, supplier relationship, manpower management, customer relationship, employee behaviour \& attitude, product design process, quality data \& reporting, process flow management, and the role of quality department. The study concluded that the use of IT has an effect on the dimensions of TQM and the implementation of TQM, each of which will have an impact on the organisation's performance. The study by Siddiqui \& Rahman, (2006)examined the increasing awareness for benefits by understanding through a synergy between information systems and TQM, and the readiness of information systems directors in India for TQM. The data were collected by mail survey questionnaires. A total of 300 Indian firms were selected for the survey as they are supposed to use TQM in their information systems unit. The study concluded that there is a dual impact relationship between TQM and information systems. The application of TQM entails the availability of the information provided by the information systems. On the other hand, the implementation of TQM develops the work of information systems.

The study by Siam, Alkhateeb, \& Al-Waqqad, (2012)aims to identify the scope to which IT has been utilised to back TQM order to recognise the role of IT in the implementation of TQM in Sohar Industrial Companies in the Sultanate of Oman. The main focus was on how IT extends assistance and support to TQM operations rather than on TQM performance. The outcomes of the study specified that the use of IT is not the same between the various TQM dimensions (leadership, human resources, important innovations, strategic planning, customer satisfaction, supplier quality, output quality, information \& analysis, and quality results). The largest level of IT support was utilised in information \& analysis, output quality reliance and important innovation. While the lowest level of IT support was utilised in quality outcomes and supplier quality. The role of IT is, therefore, used in adapting the working operations to improve product quality and the strengthening of productivity. The study by Almashaqba, (2013)tried to examine the effect of MIS on some of the chosen factors of TQM, namely performance, creditability, and teamwork. The significance of the research comes from knowing the relations between the modern administrative concepts and the new developed technology in MIS and knowing the effect of this technology on TQM. Outcomes showed a statistical effect of MIS on the institutional performance, a statistical effect of MIS on reliability and no statistical effect of MIS on the team work. The research recommended a continuous study of the relationship between the MIS and TQM. Thus, it can be concluded from the above discussion that H1, H2, H3, H4, H5, and H6: MIS indicators (system quality, information quality, service quality, use the system, user satisfaction, and net benefits) are positively related to TQM in the company under study.

According to the previous hypotheses, Figure 1 shows the research framework.

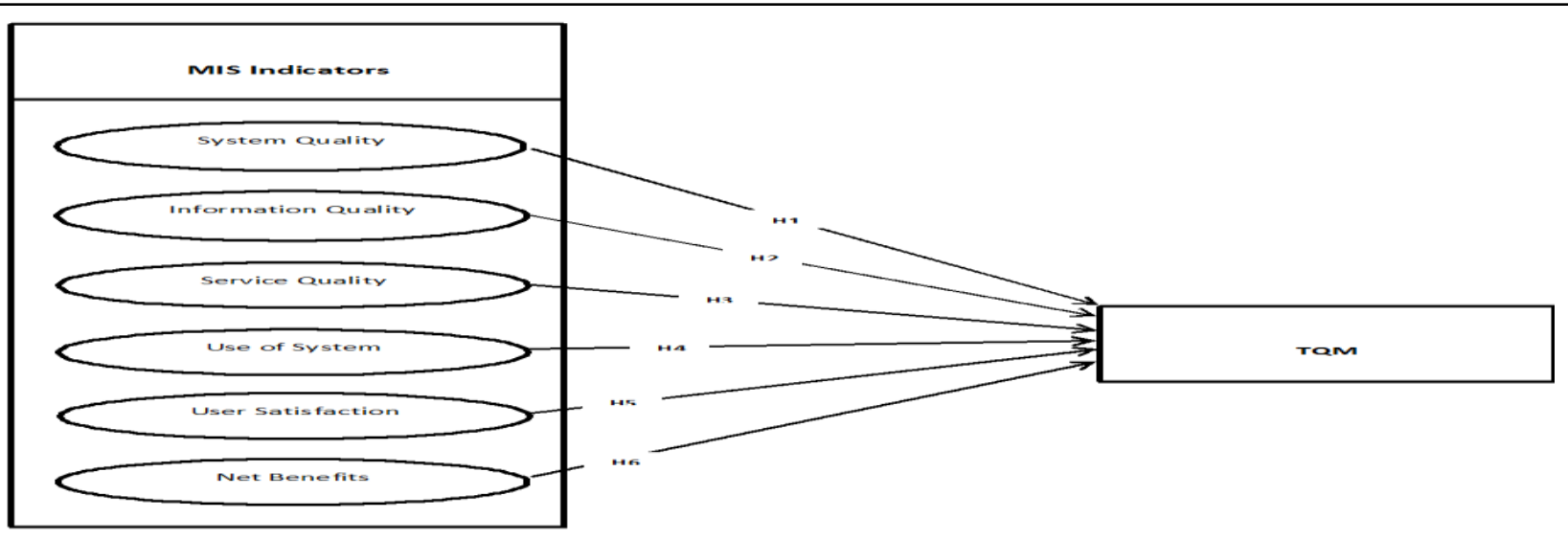




\section{Measures}

The survey method used different scales that were developed by the researchers. Nevertheless, these scales were also utilised in various contexts in the past. Consequently, this present research will validate the questionnaire in the Iraqi oil sector. The researchers followed the general guidelines for designing a questionnaire to produce a simple, attractive and standardised data collection tool that would answer the study questions. The survey involves a cover letter and the questionnaire itself. The cover letter clarifies to the respondents the major objective of the survey while emphasising the confidentiality of their answers.

The questionnaire includes three broad types of questions. Section (A) aims to collect the demographic information of the respondents, which includes 7 questions that were supposed to collect some information about the participants. The questions cover the gender of the respondent, age, education, and years in the current position, practical experience, specialisation, and tenure. Section (B) includes 24 questions that were related to MIS indicators. And lastly Section (C) includes 24 questions on TQM. The five-point Likert scale was used from 1 strongly disagrees, 2 disagrees, 3 neutral, 4 agrees, and 5 strongly agrees for measuring the statement for each respective sub-question.

The model by Delone \& Mclean, (1992)on information systems success and the updated version by DeLone \& McLean, (2003) is used to measure MIS, which includes six indicators, namely system quality, information quality, service quality, use of system, user satisfaction and net benefits. Each indicator has four items as presented in Table 1.

Table 1: Summary Item for MIS Indicators.

\begin{tabular}{|c|c|c|}
\hline Variables & Items & References \\
\hline System Quality & $\begin{array}{l}\text { The MIS in my company is easy to use. } \\
\text { The functions of the MIS in my company meet my requirements. } \\
\text { The MIS in my company is always available. } \\
\text { The MIS in my company is safe. }\end{array}$ & $\begin{array}{l}\text { (Seddon \& Kiew, } \\
\text { 1996) } \\
\text { (Allour, 2010) } \\
\text { (Halawi, 2005) } \\
\text { (Gay, 2012) }\end{array}$ \\
\hline Information Quality & $\begin{array}{l}\text { The MIS in my company presents information in a useful format and is } \\
\text { understandable. } \\
\text { The MIS in my company often presents information at a time suitable } \\
\text { for its use. } \\
\text { The MIS in my company provides more current (up-to-date) } \\
\text { information. } \\
\text { The MIS in my company provides the beneficiaries with accurate } \\
\text { information. }\end{array}$ & $\begin{array}{l}\text { (Allour, 2010) } \\
\text { (Almutairi,2001) } \\
\text { (Elmorshidy,2004) } \\
\quad(\text { Gay, 2012) }\end{array}$ \\
\hline Service Quality & $\begin{array}{l}\text { The response time of the MIS in my company is good. } \\
\text { The MIS in my company provides a decent service for users. } \\
\text { The service quality of the MIS in my company affects the extent to } \\
\text { which the system can be used. } \\
\text { My company has specialists in MIS to address technical problems and } \\
\text { emergencies if any. }\end{array}$ & $\begin{array}{l}\text { (Allour, 2010) } \\
\text { (Elmorshidy, } \\
\text { 2004) } \\
\text { (Halawi, 2005) } \\
\text { (Gay, 2012) }\end{array}$ \\
\hline Use of System & $\begin{array}{l}\text { I often use the MIS applied in my company. } \\
\text { I am very interested in the process of continuing to use the MIS in my } \\
\text { company to accomplish the tasks entrusted to me. } \\
\text { The human and material resources supporting the MIS in my company } \\
\text { have helped its success. } \\
\text { The number of participants in the use of MIS in my company has been } \\
\text { constantly increasing since its inception. }\end{array}$ & $\begin{array}{l}\text { (Gay, 2012) } \\
\text { (Elmorshidy, } \\
\text { 2004) } \\
\text { (Halawi, 2005) }\end{array}$ \\
\hline User Satisfaction & $\begin{array}{l}\text { Using my company's MIS helps improve productivity. } \\
\text { The MIS in my company is very efficient. } \\
\text { The MIS in my company is flexible enough. } \\
\text { I am satisfied with the accuracy and objectivity of my company's MIS. }\end{array}$ & $\begin{array}{l}\text { (Allour, 2010) } \\
\text { (Halawi, 2005) } \\
\text { (Elmorshidy, } \\
\text { 2004) } \\
\text { (Seddon \& Kiew, } \\
\text { 1996) }\end{array}$ \\
\hline Net Benefits & $\begin{array}{l}\text { Using the MIS in my company helps reduce the time allotted to } \\
\text { accomplish my tasks. } \\
\text { Using the MIS in my company will improve my job performance. } \\
\text { The application of the MIS in my company helps increase productivity. } \\
\text { The MIS in my company enhances the effectiveness of my job. }\end{array}$ & $\begin{array}{c}(\text { Gay, 2012) } \\
\text { (Seddon \& Kiew, } \\
\text { 1996) }\end{array}$ \\
\hline
\end{tabular}


The model by Malcolm Baldrige National Quality Award (MBNQA) 1987 is used to measure TQM, which includes six practices, namely the practices of leadership, customer focus, human resource management, strategic planning, process management, and information\& analysis. Each practice has four items. The preparation of these items has been based on Prajogo \& Sohal, (2006), these items the scale are divided as presented in Table 2.

Table 2: Summary Items for TQM

\begin{tabular}{|c|c|}
\hline Practices & Items \\
\hline $\begin{array}{l}\text { The Practices } \\
\text { of Leadership }\end{array}$ & $\begin{array}{l}\text { Senior management in my company has similar beliefs about my company's future direction. } \\
\text { Senior management in my company often cares about changes and supports the } \\
\text { implementation of a culture of improvement, learning and innovation to achieve } \\
\text { "excellence". } \\
\text { Employees in my company have the opportunity to participate in the implementation of the } \\
\text { change procedures required. } \\
\text { My company has a high level of target unit at the individual and department level without } \\
\text { any barriers. }\end{array}$ \\
\hline $\begin{array}{l}\text { Customer } \\
\text { Focus }\end{array}$ & $\begin{array}{l}\text { My company constantly gets input from customers to identify and meet their needs and } \\
\text { expectations. } \\
\text { My company has close relationships with its customers and works to create easy channels to } \\
\text { communicate with them. } \\
\text { My company constantly listens to customer's complaints and works to solve them first hand. } \\
\text { My company uses a variety of methods to measure customer satisfaction. }\end{array}$ \\
\hline $\begin{array}{c}\text { Human } \\
\text { Resource } \\
\text { Management }\end{array}$ & $\begin{array}{l}\text { My company conducts ongoing training programmes to develop staff capabilities including } \\
\text { jobs planning. } \\
\text { My company is interested in measuring employee satisfaction periodically and regularly. } \\
\text { My company runs two-way communication from "top to bottom" and "bottom to top". } \\
\text { My company always cares about maintaining a working environment to ensure the health and } \\
\text { safety of all employees. }\end{array}$ \\
\hline $\begin{array}{l}\text { Strategic } \\
\text { Planning }\end{array}$ & $\begin{array}{l}\text { My company establishes a clear vision supported by all employees to determine the direction } \\
\text { of its future business. } \\
\text { My company uses comprehensive planning tools that contribute to the review of short and } \\
\text { long-term goals. } \\
\text { My company pays great attention to developing its plans, policies and objectives to meet the } \\
\text { aspirations of all stakeholders and the community. } \\
\text { My company adopts a major strategy with the approval of senior management covering all } \\
\text { operations and at all levels. }\end{array}$ \\
\hline $\begin{array}{c}\text { Process } \\
\text { Management }\end{array}$ & $\begin{array}{l}\text { My company maintains clear and documented instructions that are understood by all } \\
\text { employees about the procedures. } \\
\text { My company adopts advanced statistical methods in improving processes and reducing } \\
\text { contrast. } \\
\text { My company continues to establish strategic partnerships with suppliers. } \\
\text { My company has a supplier evaluation guide and rating according to internationally accepted } \\
\text { performance standards. }\end{array}$ \\
\hline $\begin{array}{c}\text { Information \& } \\
\text { Analysis }\end{array}$ & $\begin{array}{l}\text { My company uses an effective performance measurement system to assess overall } \\
\text { organisational performance. } \\
\text { Data and information about my company's performance are always available to the relevant } \\
\text { parties. } \\
\text { The senior management of my company meets regularly to determine its performance and } \\
\text { use it as a basis for future decisions. } \\
\text { My company compares consistently with similar companies in the field of work. }\end{array}$ \\
\hline
\end{tabular}

\section{Population and sample}

The researchers adopted the probability sampling in order to make a generalisation of the findings of study method utilising a sample of respondents. Among several types of probabilistic sampling, the researchers choose random sampling as the sampling method for the current research (Fraenkel, Wallen, \& Hyun, 2015). 
The population used for this study consists of managers from high, middle and low levels at Missan Oil Company which is operating in southern Iraq. The study sample was derived from Krejcie \& Morgan, (1970). Accordingly, the sample size for a population of approximately 298 is 169 . The sample size of the current study will be 250 , for it to be considered as adequate and satisfactory to yield a confidence level of $95 \%$ with a $5 \%$ sampling error.

\section{Results}

In this research, although 250 questionnaires were distributed but only 219 questionnaires were returned during the data collecting process. This represents a response rate of 87.6\%.After the initial data filtering process, 201 completed questionnaires were selected. The employee profile of the 201 respondents is illustrated in Table 3 which shows that there are more male employees $(77.1 \%)$ than their female counterparts (22.9\%). In terms of age, a majority with $58.2 \%$ of the total respondents is below 30 years old followed by (29.4\%) aged between 31-40 years old. The other age groups are distributed as follows: $41-50(10.9 \%)$, and above $50(1.5 \%)$. Majority of the respondents (60.7\%) are Bachelor degree holders, (29.1\%) with professional qualification level, Baccalaureate / Diploma holders, (36.3), (3\%) Master holders and no one holds a $\mathrm{PhD}$ doctorate. In terms of experience, $(39.3 \%)$ of the total respondents have less than 5 years of working experience in the present organisation, the other experienced groups are distributed as follows: 6-10 (27.3\%), 11-15 (19.9), 16-20 (9.5), and above $20(4 \%)$. From the perspective of the job positions level by the respondents in the organisation, $(74.1 \%)$ are either managers of unit or section. Only $20.9 \%$ are managers of department, and the remaining 5\% are senior managers such as general managers and directors. In terms of job position length, a majority with $58.6 \%$ of the total respondents were having experience between $1-5$ years, followed by $29.4 \%$ length of job position 6-10 years, whilst 17\% of respondents have above than 10 years in this field.

Table 3: Demographic Profile of Respondent

\begin{tabular}{|c|c|c|c|}
\hline Profile & Categories & Frequency & Percent \\
\hline \multirow{2}{*}{ Gender } & Male & 155 & 77.1 \\
\hline & Female & 46 & 22.9 \\
\hline \multirow{4}{*}{ Age } & Below 30 Years & 117 & 58.2 \\
\hline & 31-40 Years & 59 & 29.4 \\
\hline & 41-50 Years & 22 & 10.9 \\
\hline & Above 50 Years & 3 & 1.5 \\
\hline \multirow{4}{*}{ Education } & Baccalaureate / Diploma & 73 & 36.3 \\
\hline & $\begin{array}{c}\text { Bachelor Degree/Professional } \\
\text { Qualification }\end{array}$ & 122 & 60.7 \\
\hline & Master Degree & 6 & 3 \\
\hline & PhD Degree & 0 & 0 \\
\hline \multirow{5}{*}{ Experience } & Less than 5 Years & 79 & 39.3 \\
\hline & $6-10$ Years & 55 & 27.3 \\
\hline & $11-15$ Years & 40 & 19.9 \\
\hline & $61-20$ Years & 19 & 9.5 \\
\hline & Above 20 Years & 8 & 4 \\
\hline \multirow{3}{*}{ Level of job position } & Manager of Unit or Section & 149 & 74.1 \\
\hline & Manager of Department & 42 & 20.9 \\
\hline & $\begin{array}{l}\text { General Manager/ Deputy General } \\
\text { Manager / Manager of Division }\end{array}$ & 10 & 5 \\
\hline \multirow{4}{*}{ Length of job position } & Less than 2 Years & 59 & 29.3 \\
\hline & $3-5$ Years & 59 & 29.3 \\
\hline & $6-10$ Years & 49 & 24.4 \\
\hline & Above 10 Years & 34 & 17 \\
\hline
\end{tabular}

\section{Measurement model}

In the present research, SEM was utilised to test the measurement and structural model using AMOS 21 software. As a prerequisite for testing the relationship of the obvious item with their respective latent constructs, the confirmatory factor analysis (CFA) was performed as recommended by Hair et al., (2010). The findings showed that all the values are within the accepted range(Byrne, 2001). The measurement model was tested in two steps. First, all measurement models were examined individually with the latent constructs of system quality, information quality, service quality, use of system, user satisfaction, net benefits and TQM. 
The results suggested that items SQ31, SQ4, US1, NB4, CF1, HR2, PM1 andIA2 were found to have unacceptable low factor loadings of less than 0.5. Consequently, these factors were dropped from the analysis. Then, all the measurement models were tested jointly till fruition the model fitness and validity and reliability issue. Figure 2 shows the results for CFA.

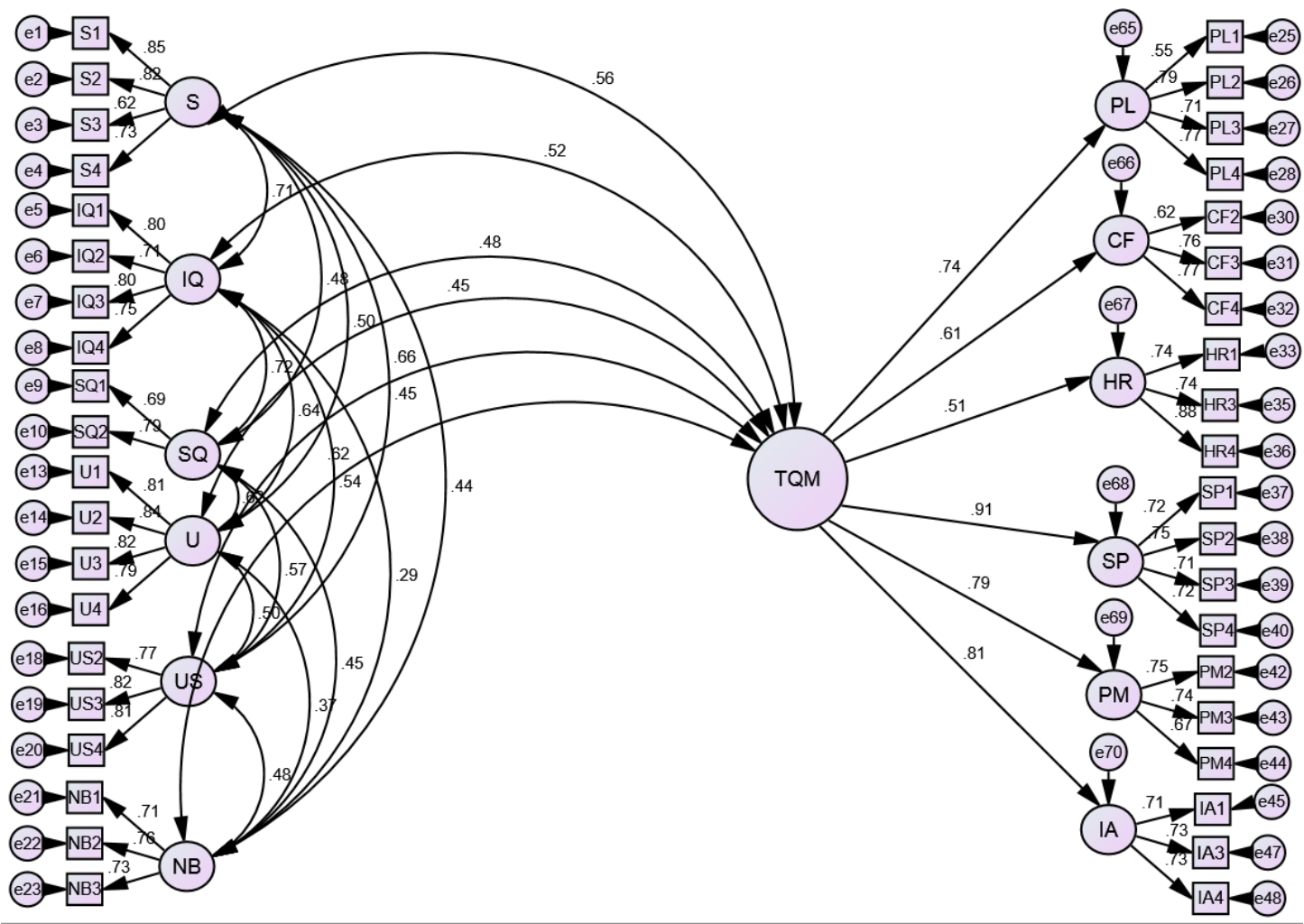

Figure 2: Overall Measurement Models of All Constructs

The results showed there is sufficient improvement in the fit values of the model with $\mathrm{df}=713$. The Chi square for this model is $\chi^{2}=992.987, \chi 2 / \mathrm{df}=1.393, \mathrm{RMR}=0.064, \mathrm{SRMR}=0.0531, \mathrm{CFI}=0.927, \mathrm{TLI}=0.920$ and $\mathrm{RMSEA}=0.044$, which demonstrate the fitness of the model as presented in Table 4.

Table 4: Overall Measurement Model

\begin{tabular}{|c|c|c|c|}
\hline \multirow{2}{*}{ Statistics } & Fit Indices & $\begin{array}{c}\text { Level of } \\
\text { Acceptance }\end{array}$ & $\begin{array}{c}\text { Obtained Model } \\
\text { fitness value }\end{array}$ \\
\hline \multirow{4}{*}{ Absolute Fit } & $\chi 2$ & $\mathrm{P}>0.05$ & 992.987 \\
\cline { 2 - 4 } & $\mathrm{DF}$ & & 713 \\
\cline { 2 - 4 } & $\mathrm{CMIN/DF}$ & $<5$ & 1.393 \\
\cline { 2 - 4 } & $\mathrm{RMR}$ & $<0.8$ & 0.064 \\
\hline \multirow{2}{*}{ Incremental Fit } & SRMR & $>0.8$ & 0.0531 \\
\cline { 2 - 4 } & $\mathrm{CFI}$ & $>0.90$ & 0.927 \\
\hline Parsimony Fit & TLI & $<0.8$ & 0.920 \\
\hline
\end{tabular}

CMIN/DF =Normed Chi-Square; $\chi 2=$ Chi-square; $\mathrm{DF}=$ Degree of Freedom; Minimum Chi-square; CFI= Comparative Fit Index; TLI= Tucker Lewis; RMR= Root Mean Square Residual; RMSEA= Root Mean Square Error of Approximation and SRMR=Standardized Root Mean Square Residual.

\subsection{Convergent validity}

Convergent validity is described as the level agreed upon by many of the items that measure the same concept (Ramayah, Lee, \& In, 2011). As suggested by Hair et al., (2010), the construct convergent validity can be evaluated utilising item loadings, average variance extracted (AVE) and composite reliabilities (CR) of the construct. All the item loadings must be over than 0.50 as recommended by Fornell \& Larcker, (1981). The AVE of every construct must be above 0.50 based on Kline, (2010). 
In addition, $\mathrm{CR}$ values represent the level to which the construct indicators discover the latent variable and they must be above 0.70 as recommended by Cooper \& Schindler, (2013). Table 5displays that the values of AVE for all the constructs were larger than 0.50 which indicates all the constructs have sufficient convergent validity. Also, Table 5displays that all the constructs have an acceptable reliability ranging from 0.706 to 0.889 as they are larger than 0.70 . Hence, this research does not violate the constructs convergent validity.

Table 5: Convergent Validity Analysis

\begin{tabular}{|c|c|c|}
\hline Constructs & AVE & CR \\
\hline System Quality & 0.577 & 0.843 \\
\hline Information Quality & 0.583 & 0.848 \\
\hline Service Quality & 0.546 & 0.706 \\
\hline Use of System & 0.667 & 0.889 \\
\hline User Satisfaction & 0.641 & 0.842 \\
\hline Net Benefits & 0.540 & 0.778 \\
\hline TQM & 0.546 & 0.874 \\
\hline
\end{tabular}

\subsection{Discriminant validity}

Discriminant validity is the degree in which the items of the latent construct is really different from items of all other latent constructs (Arbuckle, 2011; Hair et al., 2010). There are many ways to establish discriminant validity. The first criterion indicates that the value of inter construct correlation should be less than 0.85 in order to establish the discriminant validity(Cooper \& Schindler, 2013). A second criterion is that the square root of AVE must be larger than all inter-construct correlations of the respective construct(Fornell \& Larcker, 1981).Table 6 explains the squared interconstruct correlation of each variable and AVE. The findings denote that all the constructs have sufficient discriminant validity as the square root of AVE is higher than the inter-construct correlation of each variable and the values of inter construct are minus 0.85. It means the findings provide enough evidence of the constructs discriminant validity.

Table 6: Discriminant Validity Analysis

\begin{tabular}{|c|c|c|c|c|c|c|c|}
\hline Variables & SQ & IQ & SQ & U & US & NB & TQM \\
\hline System Quality & $\mathbf{0 . 7 5 9}$ & & & & & & \\
\hline Information Quality & 0.709 & $\mathbf{0 . 7 6 3}^{*}$ & & & & & \\
\hline Service Quality & 0.481 & 0.722 & $\mathbf{0 . 7 3 8}^{*}$ & & & & \\
\hline Use of System & 0.498 & 0.643 & 0.621 & $\mathbf{0 . 8 1 6}^{*}$ & & & \\
\hline User Satisfaction & 0.451 & 0.538 & 0.571 & 0.499 & $\mathbf{0 . 8 0 0} *$ & & \\
\hline Net Benefits & 0.437 & 0.292 & 0.448 & 0.372 & 0.483 & $\mathbf{0 . 7 3 4} *$ & \\
\hline TQM & 0.564 & 0.518 & 0.480 & 0.448 & 0.656 & 0.624 & $\mathbf{0 . 7 3 8}^{*}$ \\
\hline
\end{tabular}

*diagonal show the square root of $\mathrm{AVE}$

\section{Hypothesis testing}

SEM is utilised to provide a path analysis for exogenous and endogenous variables by AMOS 21. Figure 3 shows the relationship between MIS indicators and TQM to examine whether or not there is a statistically significant relationship. Each path presents a total variation clarified in the endogenous variable with observance to exogenous variables. The findings display the significant model fit Chi square for this model is $\chi 2=1.818, \mathrm{DF}=1, \mathrm{RMR}=0.026$ it should be near0, $\mathrm{SRMR}=0.0249$ whichshould also be near $0, \mathrm{TLI}=0.940$ which is near to $1, \mathrm{CFI}=0.997$ is also near to 1 represents a perfect fit, RMSEA=0.064 from 0.05 to 0.08 represents modesty in model. 


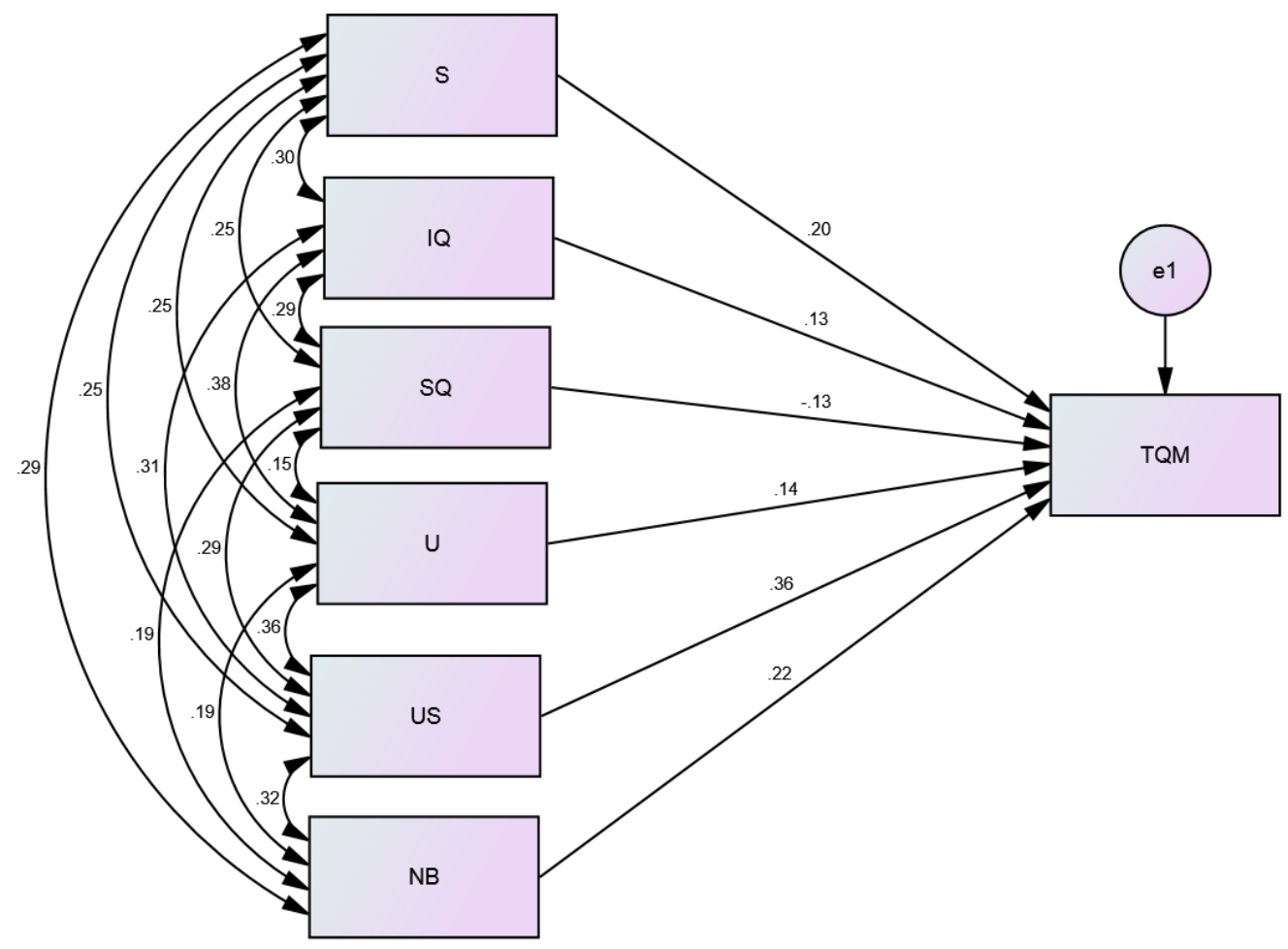

Figure 3: Results of structural model

First hypothesis states that H1: System quality is positively related to TQM. Table 7 shows that path H1: System quality $\rightarrow$ TQM have an unstandardised estimate of 0.118 , standardised path coefficient of 0.20 , standard error of 0.035 , and the critical ratio was 3.373 with a $\mathrm{p}$ value of 0.000 , which is less than 0.05 . This proves there is sufficient evidence to agree to the study hypothesis. Consequently, H1 was accepted. The research established a direct relationship between system quality and TQM.

Table 7: Hypothesis results

\begin{tabular}{|c|c|c|c|c|c|c|c|}
\hline \multicolumn{3}{|c|}{ Path } & Estimate & S.E. & C.R. & $\mathbf{P}$ & Label \\
\hline TQM & $<---$ & $\mathrm{S}$ & 0.118 & 0.035 & 3.373 & $* * *$ & Significant \\
\hline TQM & $<--$ & IQ & 0.073 & 0.035 & 2.087 & 0.037 & Significant \\
\hline TQM & $<--$ & SQ & -0.073 & 0.032 & -2.292 & 0.022 & $\begin{array}{c}\text { Significant } \\
\text { Relationship } \\
\text { Negative }\end{array}$ \\
\hline TQM & $<--$ & $\mathrm{U}$ & 0.076 & 0.032 & 2.372 & 0.018 & Significant \\
\hline TQM & $<--$ & US & 0.233 & 0.039 & 5.920 & $* * *$ & Significant \\
\hline TQM & $<--$ & NB & 0.163 & 0.043 & 3.821 & $* * *$ & Significant \\
\hline
\end{tabular}

Second hypothesis states that H2: Information quality is positively related to TQM. Table 7 shows that path $\mathrm{H} 2$ : Information quality $\rightarrow$ TQM have an unstandardised estimate of 0.073 , standardised path coefficient of 0.13 , standard error of 0.035 , and the critical ratio was 2.087 with a $\mathrm{p}$ value of 0.037 , which is less than 0.05 . This proves there is sufficient evidence to agree to the study hypothesis. Consequently, $\mathrm{H} 2$ was accepted. The research established a direct relationship between information quality and TQM.

Third hypothesis states that H3: Service quality is positively related to TQM. Table 7 shows that path H3: Service quality $\rightarrow \mathrm{TQM}$ have an unstandardised estimate of- 0.073 , standardised path coefficient of -0.13 , standard error of 0.032 , and the critical ratio was -2.292 . The hypothesis was established to test the positive relationship. For this reason, the $\mathrm{H} 3$ has been rejected and the research established a negative relationship between service quality and TQM.

Fourth hypothesis states that H4: Use MIS is positively related to TQM. Table 7 shows that path H4: Use of system $\rightarrow$ TQM have an unstandardised estimate of 0.076 , standardized path coefficient 0.14 , standard error of 0.032 , and the critical ratio was 2.372 with a $\mathrm{p}$ value of 0.018 , which is less than 0.05 . 
This proves there is sufficient evidence to agree to the study hypothesis. Consequently, $\mathrm{H} 4$ was accepted. The research established a direct relationship between use of system and TQM. Fifth hypothesis states that H5: User satisfaction is positively related to TQM. Table 7 shows that path H5: User satisfaction $\rightarrow$ TQM have an unstandardised estimate of 0.233 , standardised path coefficient of 0.36 , standard error of 0.039 , and the critical ratio was 5.920 with a $\mathrm{p}$ value 0.000 , which is less than 0.05 . This proves there is sufficient evidence to agree to the study hypothesis. Consequently, H5 was accepted. The research established a direct relationship between user satisfaction and TQM.

Sixth hypothesis states that H6: Net benefits are positively related to TQM. Table 7 shows that path H6: Net benefits $\rightarrow$ TQM have an unstandardised estimate of 0.163 , standardised path coefficient 0.22 , standard error of 0.043 , and the critical ratio was 3.821 with a $\mathrm{p}$ value 0.000 , which is less than 0.05 . This proves there is sufficient evidence to agree to the study hypothesis. Consequently, H6 was accepted. The research established a direct relationship between net benefits and TQM.

\section{Conclusion}

This paper aims to examine the relationship between MIS indicators with TQM. The findings of the current study revealed that MIS indicators system quality, information quality, use of system, user satisfaction and net benefits are more relevant to enhance TQM at Missan Oil Company.

Increasingly, enterprises found that the information systems are key success factors of TQM. Therefore, the ability to manage quality information is one of the factors required for working on the success of the TQM application(Lin et al., 2012).According to Fok, et al, (2001)TQM and information system have common objectives.

The results of similar researchers have indicated a positive relationship between MIS and TQM directly or indirectly such as Almashaqba, (2013); Lin et al., (2012);Zbar, (2009;:Spencer \& Duclos, (1998). The role of quality is a critical issue for information systems, as information is one of the most valuable assets of an organisation (Cheon \& Stylianou, 2001). According to Fok et al., (2001)companies that have incorporated TQM fully will approach the design/developing of a new information system which is very different from those that have not.

Moreover, results of many researchers have indicated a positive relationship between service quality and TQM such as Pattanayak, Koilakuntla, \& Punyatoya, (2017);Hawary \& Laimon, (2013);Lam, Lee, Ooi, \& Phusavat, (2012);Sit, Ooi, Loke, \& Han, (2011);Talib, Rahman, Qureshi, \& Siddiqui, (2011). But the findings of the current study indicated that service quality is not related to TQM at Missan Oil Company. This result implicitly correlates with the findings of Dahlgaard, Kristensen, Kanji, Juhl, \& Sohal, (1998)as they emphasised that a big gap exists between the successes of TQM on the information system in many companies.

Consequently, the results indicated that the current study had achieved its objective. Overall, the study findings suggested that system quality, information quality, use of system, user satisfaction and net benefits have a positive influence on TQM. Whilst service quality has no relationship with TQM at Missan Oil Company.

\section{Acknowledgement}

The authors are thankful to the anonymous reviewers whose constructive suggestions and corrections have improved the quality of this paper. The authors are also grateful to Missan Oil Company. The facilities provided by the Sultan Idris Education University (UPSI), are gratefully acknowledged.

\section{References}

Allour, K. F. (2010). A research study on the relationship between critical success factor management maturity and user satisfaction with ERP implementation projects. ProQuest Dissertations and Theses. Lawrence Technological University. Retrieved from http://search.proquest.com/docview/757375727?accountid=41453

Almashaqba, Z. (2013). Management Information System and their role in Total Quality Mangement,A Study in qualified industrial zone in Mafraq- Jordan. Interdisciplinary Journal of Contemporary Research in Business, 5(4), 757-776.

Almutairi, H. M. F. (2001). Evaluating information system success in public organizations: A theoretical model and empirical validation. ProQuest Dissertations and Theses.

Arbuckle, J. (2011). IBM SPSS Amos 20 User's guide. Amos Development Corporation.

Byrne, B. M. (2001). Structural Equation Modeling With AMOS, EQS, and LISREL: Comparative Approaches to Testing for the Factorial Validity of a Measuring Instrument. International Journal of Testing, 1(1), 55-86. https://doi.org/10.1207/S15327574IJT0101_4 
Cheon, M. J., \& Stylianou, A. C. (2001). Total quality management for information systems: An empirical investigation. Journal of Global Information Technology Management, 4(4), 32-52. https://doi.org/10.1080/1097198X.2001.10856313

Cooper, D., \& Schindler, P. (2013). Business Research Methods (12th ed). New York: New Yourk. McGraw-Hill / Irwin.

Dahlgaard, J. J., Kristensen, K., Kanji, G. K., Juhl, H. J., \& Sohal, A. S. (1998). Quality management practices: A comparative study between East and West. International Journal of Quality and Reliability Management, 15(8), 812-826. https://doi.org/10.1108/02656719810791675

Delone, W. H., \& Mclean, E. R. (1992). Information Systems Success: The Quest for the Dependent Variable. Information Systems Research, 3(1), 60 - 95.

DeLone, W. H., \& McLean, E. R. (2003). The DeLone and McLean Model of Information Systems Success: A TenYear Update. Journal of Management Information Systems, 19(4), 9-30. https://doi.org/10.1080/07421222.2003.11045748

Dewhurst, F. W., Martínez-Lorente, A. R., \& Sánchez-Rodríguez, C. (2003). An initial assessment of the influence of IT on TQM: a multiple case study. International Journal of Operations \& Production Management, 23(4), 348-374. https://doi.org/10.1108/01443570310467302

Elmorshidy, A. (2004). Information Systems (IS) Success in Non-Organizational Contexts: Examining the DeLone \& McLean IS Success Model in the Context of an Online Stock Trading Environment. ProQuest Dissertations and Theses. Claremont Graduate University.

Fok, L. Y., Fok, W. M., \& Hartman, S. J. (2001). Exploring the relationship between total quality management and information systems development. Information \& Management, 38(6), 355-371. https://doi.org/10.1016/S0378-7206(00)00075-6

Fornell, C., \& Larcker, D. F. (1981). Structural Equation Models with Unobservable Variables and Measurement Error: Algebra and Statistics. Journal of Marketing Research, 18(3), 382-388.

Fraenkel, J., Wallen, N., \& Hyun, H. (2015). How to design and evaluate research in education (9th ed). New York: Mcgraw Hill.

Gay, G. H. E. (2012). A study of technological barriers to Instructor E-Readiness in an online environment. ProQuest Dissertations and Theses. Nova Southeastern University. Retrieved from

http://search.proquest.com/docview/926414300?accountid=17396\%5Cnhttp://qq8fs9fh5t.search.serialssolution s.com/?ctx_ver=Z39.88-2004\&ctx_enc=info:ofi/enc:UTF-

8\&rfr_id=info:sid/Education+Database\&rft_val_fmt=info:ofi/fmt:kev:mtx:dissertation\&rft.genre=disser

Hair, J., Black, W., Babin, B., \& Anderson, R. (2010). Multivariate Data Analysis (7th ed). New Jersey: Prentice Hall, Upper Saddle River.

Halawi, L. A. (2005). Knowledge management systems' success in knowledge-based organizations: An empirical validation utilizing the DeLone and McLean IS Success Model. ProQuest Dissertations and Theses. Retrieved from http://search.proquest.com/docview/305348631? accountid=41453

Hawary, S. I. S. Al, \& Laimon, A. A. A. A. (2013). The impact of TQM practices on service quality in cellular communication companies in Jordan. International Journal of Productivity and Quality Management, 11(4), 446. https://doi.org/10.1504/IJPQM.2013.054270

Kline, R. B. (2010). Principles and Practice of Structural Equation Modeling (3rd ed.). edn Guilford Press. New York. USA.. ISBN, 1965705777.

Krejcie, R. V, \& Morgan, D. A. (1970). Determining Sample Size for Research Activities. Educational and Psychological Measurement, 30(0), 607-610. https://doi.org/10.1177/001316447003000308

Lam, S. Y., Lee, V. H., Ooi, K. B., \& Phusavat, K. (2012). A structural equation model of TQM, market orientation and service quality: Evidence from a developing nation. Managing Service Quality, 22(3), 281-309. https://doi.org/10.1108/09604521211230996

Lin, C.-C., Chuang, H.-M., \& Shih, D.-H. (2012). Development Stage and Relationship of Mis and Tqm in the EBusiness Era. International Journal of Electronic Business Management, 10(1), 50-60. Retrieved from https://search.proquest.com/docview/1015207573?accountid=8144\%0Ahttp://sfx.aub.aau.dk/sfxaub?url_ver=Z 39.88-

2004\&rft_val_fmt=info:ofi/fmt:kev:mtx:journal\&genre=article\&sid=ProQ:ProQ\%3Aabiglobal\&atitle=DEVE LOPMENT+STAGE+AND+RELATIONSHIP+OF+MIS+AND+TQM+IN+T

Pattanayak, D., Koilakuntla, M., \& Punyatoya, P. (2017). Investigating the influence of TQM, service quality and market orientation on customer satisfaction and loyalty in the Indian banking sector. International Journal of Quality \& Reliability Management, 34(3), 362-377. https://doi.org/http://dx.doi.org/10.1108/MRR-09-20150216 
Prajogo, D., \& Sohal, A. (2006). The integration of TQM and technology/R\&D management in determining quality and innovation performance. Omega, 34(3), 296-312. https://doi.org/10.1016/j.omega.2004.11.004

Ramayah, T., Lee, J. W. C., \& In, J. B. C. (2011). Network collaboration and performance in the tourism sector. Service Business, 5(4), 411-428. https://doi.org/10.1007/s11628-011-0120-z

Seddon, P. B., \& Kiew, M.-Y. (1996). A Partial Test and Development of Delone and Mclean's Model of IS Success. Australasian Journal of Information Systems, 4(1), 90-109. https://doi.org/10.3127/ajis.v4i1.379

Siam, A. Z., Alkhateeb, K., \& Al-Waqqad, S. (2012). The Role of Information Systems in Implementing Total Quality Management. American Journal of Applied Sciences, 9(5), 666-672. https://doi.org/10.3844/ajassp.2012.666.672

Siddiqui, J., \& Rahman, Z. (2006). TQM for Information Systems: Are Indian organizations ready? Interdisciplinary Journal of Information, Knowledge, and Management, 1, 125-136.

Sit, W.-Y., Ooi, K.-B., Loke, S.-P., \& Han, G. T. W. (2011). TQM and service quality: a survey of commercial banking industry in Malaysia, 3(1), 78-91. https://doi.org/10.1016/j.optcom.2007.01.051

Spencer, M. S., \& Duclos, L. K. (1998). TQM Stress MIS. American Journal of Business, 13(1), 59-64. https://doi.org/10.1108/09574090910954864

Talib, F., Rahman, Z., Qureshi, M. N., \& Siddiqui, J. (2011). Total quality management and service quality: an exploratory study of quality management practices and barriers in service industry. Int. J. Services and Operations Management, 10(1), 94-118.

Zbar, S. A. (2009). Integration of Management Information Systems And Total Quality Management System and their Impact on the Organization performance, Field Study in the General Company for Chemical Industries Babylon. University of Babylon Journal, 2(17), 349-372. 